\section{Doctors as migrants}

\author{
John Launer
}

Migration is a dominant political issue across much of the world. The number of migrants has increased globally by $69 \%$ since 1990, and the total is now around 258 million. $^{1}$ Around a quarter are refugees, fleeing from wars, persecution, famines and other disasters. ${ }^{2}$ The rest have mainly left their homes in search of better employment prospects. Most migration therefore involves movement from poorer to richer countries. While migrants make a largely positive contribution to wealthier countries, ${ }^{3}$ anxieties about rising immigration have been a significant factor in the rise of populist right-wing governments. These anxieties contributed to the election of Donald Trump and the decision of the UK to leave the European Union (EU).

This worldwide picture provides a helpful background for understanding the emigration of doctors. Medically qualified migrants are a relatively small group but an important one. Their opportunities for study or career advancement abroad are better than most other professions because their skills are transferable and valued. At the same time, they are still likely to be caught up in the political, administrative and cultural complications that other migrants face. For some, their move is only temporary, usually for higher specialist training. For others, relocation will at some stage become permanent, as they assimilate to their new environment, gain advancement or start families. This drain of medical talent is then a considerable economic loss to the countries that originally trained them, ${ }^{4}$ as well as depleting local health services, and depriving these of some of the brightest members of each generation. $^{5}$

Most developed countries are highly dependent on their immigrant medical workforce. An estimated third of doctors in the USA are foreign born, ${ }^{6}$ while a third of all registered doctors in the UK were trained abroad. ${ }^{7}$ In both countries, some specialties and regional services rely on migrant doctors in order to function properly. In future this dependence is likely to increase: the USA has a predicted shortfall in physician numbers of up to 95000 in the next decade, ${ }^{8}$ while Britain's National Health Service (NHS) already has 10000 unfilled medical vacancies. ${ }^{9}$

Correspondence to Dr John Launer, Postgraduate Medical Journal, London WC1B 5DN, UK; johnlauner@aol.com
In spite of this, the obstacles to entering and remaining in developed countries remain formidable. Established specialists in the USA may wait many years for green cards. ${ }^{10}$ Until June of this year, there was a cap on visas for overseas doctors in the UK-even when they had invested a great deal in securing posts that had previously been impossible to fill. Meanwhile, a large number of refugee doctors cannot be deployed because their opportunities for retraining are so scarce, and around 11000 NHS doctors who hold citizenship in the EU are still waiting to hear if they will retain permanent residence when Britain is scheduled to leave next March.

\section{MIGRANT ARCHITECTS OF THE NHS}

Given this context, the publication of a new book that looks closely at one group of immigrant doctors could not be more timely. 'Migrant architects of the NHS ${ }^{11}$ is a social history of South Asian doctors who entered British general practice during a crucial phase in its history during the 1940s-1980s. Its author, Julian Simpson, spent a decade carrying out oral history interviews with 40 South Asian general practitioners (GP), their children, and medical politicians involved in developing the specialty during that period. Some of the material used in the compilation of the book, including photos, archival papers and voice recordings, is on public display at the Royal College of General Practitioners in London for the rest of this year. Although the research was carried out in just one specialty in the UK, and only with doctors born and trained in India, Pakistan, Bangladesh and Sri Lanka, the detailed individual narratives, and the author's meticulous historical and political analysis, offer a model for making sense of medical migration, and also serve as a microcosm of this.

Simpson situates South Asian GPs in Britain-over 4000 of them by the 1980 s-firmly within the wider picture of British colonial history. Some of his subjects, for example, describe being brought up an environment where relatives had served in the armed forces for the British Raj. The GPs had attended schools and medical schools shaped on British models, and read English novels. Their most respected teachers were often of English or Scottish origin, or had spent time in the UK in order to further their knowledge of western medicine and western ways. This quotation from one GP is quaintly typical of what they heard from their own role models:

They were fellows of royal colleges or they were members of various royal colleges and at that time foreign education was very important ... They used to talk about anchovy sauce and we didn't know what anchovies were and we didn't know what the sauce was ... but they used to enjoy telling us that they enjoyed every minute in England... (p 103)

\section{INSTITUTIONAL DISCRIMINATION}

Almost without exception, the migrant doctors that Simpson interviewed had planned to become hospital physicians or surgeons, intending to carry on doing this in the UK or return as specialists to their countries of origin. Instead, they found themselves in hospital jobs with no prospects and consequently moved into primary care, mainly in deprived urban areas. By 1992, over 56\% of GPs in Barking and Havering in east London, for example, had trained in South Asia. (This compared with fewer than $1 \%$ in rural Somerset). The circumstances that such led to such a trajectory were different for each person, but almost invariably they included institutional discrimination by the British hospital establishment, and haphazard workforce planning that left general practice hopelessly underprovisioned. With little support or encouragement, the doctors moved in to fill a gap that might otherwise have led general practice in much of Britain to collapse. They saved general practice and helped it to develop and thrive. In many cases, they inspired their children to become GPs in their turn, thus providing many of the leaders of this profession today.

Simpson's book describes how the GPs became embedded in their communities. As a rule, they faced far less racism from their working class patients than they did from their white medical colleagues. They became involved in trade unions, local councils and many of the other civic institutions of Great Britain. Many played a part in the modernisation of general practice and GP training, and in their Royal College. At the same time, as Simpson illustrates, governments persistently gave out confused messages about sustaining the NHS but reducing immigration at the same time. At one point, this led to an official limit on vouchers allowing doctors to work in the UK, alongside the issue of temporary entry certificates 'deliberately designed to look like a voucher' (p 80). 
As well as making the doctors appear welcome and unwelcome at the same time, this ambiguous official attitude had other perverse effects. Although Simpson does not mention the fact, racial discrimination and a lack of educational support were probably significant factors leading to a disproportionate number facing disciplinary proceedings at the General Medical Council. ${ }^{12}$ This problem has now persisted for a further generation. ${ }^{13}$

There is another aspect of these doctors' experience that is underplayed by Simpson, possibly because of reticence on the part of his informants. Many had suffered as a result of the Partition of India or from subsequent religious discrimination. In spite of this, most of them stayed strongly connected with their own towns and regions across the whole of the subcontinent, from Islamabad in the north of Pakistan to Colombo in the south of Sri Lanka. They made generous contributions to developing education and medicine there through remittances, student sponsorships, working sabbaticals and even by building clinics and health centres. I suspect that this kind of philanthropy has been common in other medical diasporas around the world too. I would also guess that it has often been a conscious act of reparation for the historical inequalities that led to emigration in the first place. The other contribution that needs to be acknowledged is the support these GPs have given to their many distinct communities in their adopted country-often through involvement in religious and communal associations or charitable institutions. In this and other ways, they have been leaders in promoting multiculturalism, and architects not only of the NHS but of postcolonial society as a whole.

Correction notice This article has been corrected since publication. There was a typographical error in the section 'Migrant architects of the NHS'.

Acknowledgements I am grateful to Dr Naureen Bhatti and Dr Anwar Khan for helpful comments on a draft of this paper.

Funding The authors have not declared a specific grant for this research from any funding agency in the public, commercial or not-for-profit sectors.

Competing interests None declared.

Patient consent Not required.

Provenance and peer review Not commissioned; internally peer reviewed.

(C) Author(s) (or their employer(s)) 2018. No commercial re-use. See rights and permissions. Published by BMJ.

A) Check for updates

To cite Launer J. Postgrad Med J 2018;94:543-544.

Published Online First 20 August 2018

Postgrad Med J 2018;94:543-544.

doi:10.1136/postgradmedj-2018-136037

\section{REFERENCES}

1 United Nations Department of Economic and Social Affairs Population Division. International migration report 2017. New York: United Nations Department of Economic and Social Affairs Population Division, 2017.

2 United Nations High Commissioner for Refugees. Global trends: forced displacement in 2017. Geneva: UNHCR, 2018.

3 Organisation for Economic Co-operation and Development. Migration policy debates: is migration good for the economy? Paris: Organisation for Economic Co-operation and Development, 2014.

4 Mills EJ, Kanters S, Hagopian A, et al. The financial cost of doctors emigrating from sub-Saharan Africa: human capital analysis. BMJ 2011;343:d7031.

5 Mensah K, Macintosh M, Henry L. The 'skills drain' of health professionals from the developing world. London: Medact, 2005.

6 Center for Workforce Studies. 2014 Physician specialty data book. Washington, DC: Association of American Medical Colleges, 2014.

7 General Medical Council. The state of medical education and practice in the UK 2017. London: General Medicial Council, 2018.

8 Association of American Medical Colleges. The complexities of physician supply and demand projections from 2016 to 2030, final report. Washington DC: IHS Market Ltd, 2018.

9 Rimmer A. Home Office scraps cap on overseas doctors. BMJ 2018;361:k2648.

10 Kavilanz P. Immigrant doctors in rural America are sick of waiting for green cards. CNN money, 28 June 2018. https://money.cnn.com/2018/06/08/news/economy/ immigrant-doctors-green-card-backlog/index.html (accessed 25 Jul 2018)

11 Simpson JM. Migrant Architects of the NHS. South Asian doctors and the reinvention of british general practice (1940s-1980s). Manchester: Manchester University Press, 2018.

12 Godlee F. The GMC, racism, and complaints against doctors. BMJ 1996:312:1314-5.

13 Rimmer A. Unconscious bias must be tackled to reduce worry about overseas trained doctors, says BAPIO. BMJ;2017:j1881. 